INTERNATIONAL JOURNAL OF RESEARCHES IN BIOSCIENCES, AGRICULTURE AND TECHNOLOGY (C) VISHWASHANTI MULTIPURPOSE SOCIETY (Global Peace Multipurpose Society) R. No. MH-659/13(N) www.vmsindia.org

\title{
ACTIVITY ASSAY OF THE ENZYMES AMYLASE, PROTEASE AND LIPASE PRODUCED BY N. INTERMEDIA MTCC 1230 AND R.OLIGOSPORUS MTCC 556 DURING PEANUT PRESS CAKE FERMENTATION
}

\author{
P. H. Kumbhare \\ Department of Microbiology, Guru Nanak College of Science, Ballarpur-442701 (M.S.), India. Email- \\ dr.kumbhareph@yahoo.com
}

\begin{abstract}
:
Fungal food fermentations in the Orient are recognized as the "indigenous or traditional fermentations" which include the very important Soy sauce, Miso, Tempeh, Oncom etc. From this traditional food fermentation processes, modern sophisticated enzyme industries have been developed. Most of the fungal food fermentations are reported to be the Solid State Fermentations (SSF). Degradation of complex constituents of the solid substrates by extracellular enzymes to simpler compounds becomes a key step in SSF process. Among many microorganisms, only filamentous fungi can grow to a significant extent in solid substrate. Among filamentous fungi, Neurospora sitophila, Neurospora intermedia and Rhizosporus oligosporus have gained practical importance in solid state fermentation. These molds are widely employed for the industrial production of many commercially valuable fermented food products and Oriental foods by solid state fermentation. Complex carbohydrates, proteins and lipids in solid substrates are degraded to simpler sugars, amino acids and free fatty acids by the extracellular enzymes Amylase, Protease, and Lipase released by fungi and modify starting solid substrates.

In our previous investigation on Peanut press cake fermentation it was reported that, the metabolic activities of the enzymes amylase, protease and lipase produced by the mold cultures brings about the biochemical changes in peanut press cake substrate during fermentation. The present study was carried out to assay the activity of the enzymes amylase, protease and lipase produced by the selected mold cultures used for laboratory scale fermentation of peanut press cake.

The comparison of enzyme activity assay after 48 hours of peanut press cake fermentation at $28^{\circ} \mathrm{C}$ reveal that, $N$. intermedia MTCC 1230 show comparatively higher activity of the enzyme Amylase (0.75 SU ml-1), Protease (180 U ml-1) and Lipase (4.60 U g-1) whereas R. oligosporus MTCC 556 show Amylase (0.57 SU ml-1), Protease (100 U ml1) and Lipase (2.60 U g-1) activity.

Keywords: Enzyme assay, Amylase, Protease, Lipase, R. oligosporus, Neurospora intermedia
\end{abstract}

\section{Introduction:}

Fungal food fermentations in the Orient are recognized as the "indigenous or traditional fermentations" which include the very important soy sauce, miso and tempeh. From this traditional food fermentation processes, modern sophisticated enzyme industries and the manufacture of flavoring agents such as monosodium glutamate and nucleotides have been developed (Blain, 1975; Miall, 1983).

Most of the fungal food fermentations are reported to be the Solid State Fermentations (SSF). Most practical substrates used for SSF processes are the starchy materials, grains, cereals, tuber-roots, pulses and oilseeds. Degradation of complex constituents of the solid substrates by extracellular enzymes to simpler compounds becomes a key step in SSF process. Complex carbohydrates, proteins and lipids in solid substrates are degraded to simpler sugars, amino acids and free fatty acids by the extracellular enzymes Amylase, Protease, Lipase etc. released by fungi and enhance digestibility of starting materials (Arasaratnam et al., 2001). Many microorganisms such as bacteria, yeasts and molds are used to prepare Oriental fermented foods however only filamentous fungi can grow to a significant extent in solid substrate. Among the filamentous fungi, $\boldsymbol{N}$. sitophila, N. intermedia and $R$. oligosporus have gained practical importance in solid state fermentation.

An investigation was carried out (Kumbhare et al., 2000, 2003) to study the biochemical changes occurring in the solid state fermentation of peanut press cake by using the mold cultures, N. intermedia MTCC 1230 and R. oligosporus MTCC 556. The physicochemical and nutritional property of PPC changes significantly due to solid state fermentation by the molds (Van Veen et. al. 1968,). Major changes in color, flavor, texture, increased digestibility and nutritive value in fermented PPC are brought about by metabolic and enzymatic activities of the cultivated mold cultures (Steinkraus, 1983). It has been noted that the enzymes amylase, protease and lipase produced by the inoculated molds degrade PPC constituents i.e. carbohydrates, protein, lipids and making it more digestible and at the same time more flavorful (Beuchat, 1983; Kovac, 1997).

In our investigation more emphasis was given to study the activity of extracellular enzymes amylase protease and lipase produced 
by the selected mold cultures and the biochemical changes occurring in laboratory scale fermentation of peanut press cake (Kumbhare, 2011).

The present study was carried out to assay the activity of the enzymes amylase, protease and lipase produced by the molds, $\boldsymbol{N}$. intermedia MTCC 1230 and R. oligosporus MTCC 556 during PPC fermentation. To assay the enzyme activity the mold cultures were cultivated on Peanut press cake substrate and fermented at $28^{\circ} \mathrm{C}$ for 48 hours. After fermentation, the activity of the enzymes amylase, protease and lipase was estimated by appropriate assay method.

\section{Material and Methods:}

Substrate: The substrate used for the solid state fermentation is Peanut Press Cake (PPC) (Beuchat, 1976). The residue that remains after oil extraction by Expeller from Peanut (Groundnut $=$ Arachis hypogea) is known as Peanut press cake or Groundnut cake. It was procured from a local oil mill in Ballarpur.

Mold Cultures: The mold cultures, N.intermedia MTCC 1230 and R.oligosporus MTCC 556 were used for laboratory scale fermentation of PPC to assay the enzyme activity. The mold cultures were obtained from Microbial Type Culture Collection (MTCC), Institute of Microbial Technology (IMTech) Institute of Microbial Technology (IMTech), Chandigarh (India). It was maintained by growing on Potato Dextrose Agar (PDA, Himedia M096) and sub-cultured monthly.

Mold culture inoculum: Mold culture inoculum for PPC fermentation was prepared from seven day old sporulated culture of molds grown on PDA slants at $28^{\circ} \mathrm{C}$. Ten $\mathrm{ml}$ of sterile distilled was added to prepare spore suspension and 1 $\mathrm{ml}$ of this spore suspension was used as inoculum to inoculate $25 \mathrm{gm}$. of overnight soaked PPC substrate for fermentation.

Laboratory scale fermentation of PPC: Peanut press cake was fermented on laboratory scale under optimized process conditions. A $25 \mathrm{gm}$. of overnight soaked and autoclaved PPC in a 250 $\mathrm{ml}$ Erlenmeyer flask was inoculated separately with $1 \mathrm{ml}$ spore suspension of N.intermedia MTCC 1230 and R.oligosporus MTCC 556 and incubated at $280 \mathrm{C}$ for 48 hours. One flask containing $25 \mathrm{gm}$. of overnight soaked and autoclaved PPC without inoculation (unfermented) was kept as a Control.

Chemicals, Culture media and Reagents: The chemicals, culture media and reagents required for enzymes assay were procured from Himedia laboratories Pvt. Ltd.; S.D. Fine Chem. Ltd., Mumbai (India).

\section{Methods of Enzyme Assay}

i) Amylase assay:

Fermented PPC extract: One gram of laboratory scale fermented PPC after 48 hours was removed aseptically from each flask separately. It was mixed with $9 \mathrm{ml}$ of sterile distilled water and centrifuged at 10,000 rpm for 10 min. Supernatant was filtered through Whatman No. 42. The collected cell free filtrate (PPC extract) was used as test sample to assay amylase activity.

Method: Amylase activity was assayed by a method of Somogyi (1938), by measuring amount of liberated glucose due to the activity of amylase on soluble starch. Five $\mathrm{ml}$ of phosphate-buffer-starch-substrate $(0.1 \mathrm{M}, \mathrm{pH}$ 7.0, containing starch-1\% $\mathrm{w} / \mathrm{v}$ ) initially equilibrated to $37 \mathrm{oC}$ for $5 \mathrm{~min}$ was mixed with $0.1 \mathrm{ml}$ of fermented PPC extract. Reaction mixture was incubated at $37 \mathrm{oC}$ for $15 \mathrm{~min}$. Amylase activity was terminated after $15 \mathrm{~min}$ by adding $1 \mathrm{ml}$ of $2 \mathrm{~N} \mathrm{NaOH}$ and made up the volume to $9.6 \mathrm{ml}$ by adding sterile distilled water. A $0.4 \mathrm{ml}$ of $0.01 \mathrm{~N}$ iodine solution was then added and optical density was determined in a Colorimeter at $640 \mathrm{~nm}$ using a blank containing $9.6 \mathrm{ml}$ of sterile distilled water and $0.4 \mathrm{ml}$ of $0.01 \mathrm{~N}$ iodine solution. Control was prepared by arresting amylase activity before incubation by adding $1 \mathrm{ml}$ of $2 \mathrm{~N} \mathrm{NaOH}$ and followed the procedure as for test sample. Amylase activity was calculated using a standard formula (Somogyi, 1938).

One Somogyi unit of amylase was defined as the amount of enzyme which hydrolyzes starch liberating one micromole of glucose per $\mathrm{ml}$ per min under the assay conditions and expressed as Somogyi units per $\mathrm{ml}$ (SU ml-1). The results of amylase assay are shown in Table 1, Figure. 1.A.

\section{ii) Protease assay}

Fermented PPC extract: The fermented PPC extract prepared and used for amylase assay was used for the assay of protease activity.

Method: Protease activity was estimated by a modified Lowry's method (Lowry, 1951) using casein as an enzyme substrate and reagent Follin-Ciocalteu, (1927).

Two $\mathrm{ml}$ of citrate-phosphate buffer $(0.1 \mathrm{M} \mathrm{pH} 7.0)$ initially equilibrated to $37^{\circ} \mathrm{C}$ for 5 min was mixed with $1 \mathrm{ml}$ of $1 \%$ casein solution and $1 \mathrm{ml}$ of PPC extract. Reaction mixture was incubated at $37^{\circ} \mathrm{C}$ for $10 \mathrm{~min}$. After 10 minutes, protease activity was terminated by adding $2 \mathrm{ml}$ of ice cold $10 \%$ Trichloro acetic acid (TCA) to 
precipitate out un-hydrolyzed casein and incubated further for $30 \mathrm{~min}$ at $37^{\circ} \mathrm{C}$. After incubation un-hydrolyzed casein was removed by filtration (Whatmann No. 42). One $\mathrm{ml}$ of filtrate was mixed with $2.5 \mathrm{ml}$ of $0.5 \mathrm{~N} \mathrm{NaOH}$, $1 \mathrm{ml}$ of sterile distilled water and $0.5 \mathrm{ml}$ of FollinCiocalteu reagent (1:5 diluted). After 10 minute tyrosine content librated due to protease activity was measured at $540 \mathrm{~nm}$ in a Colorimeter (Systronic digital type 141) using blank containing $2 \mathrm{ml}$ of $0.5 \mathrm{~N} \mathrm{NaOH} ; 1 \mathrm{ml}$ of sterile distilled water and $0.5 \mathrm{ml}$ of Follin-Ciocalteu reagent. Control was prepared by terminating protease activity by adding $2 \mathrm{ml}$ of $10 \%$ TCA before incubation and followed the same protocol as for test sample. Protease activity was calculated from a standard curve of tyrosine.

One unit of protease activity was defined as the amount of enzyme liberating one micromole of tyrosine per $\mathrm{ml}$ per min under the assay conditions and expressed as units per $\mathrm{ml}$ ( $\mathrm{U} \mathrm{ml}-1)$. The results of this assay are shown in

Table 1, Figure. 1.B.

iii) Lipase assay

Fermented PPC extract: Five gram of laboratory scale fermented PPC was removed aseptically from each mold cultivated flask separately and homogenized with twice the volume of ice cold acetone. Suspension was filtered (Whatman No.42) and residue quickly washed successively with acetone, acetone:ether $(1: 1 \mathrm{~V} / \mathrm{V})$; ether and then air dried. One gram of dried extract was mixed with $9 \mathrm{ml}$ of ice-cold sterile distilled water for $15 \mathrm{~min}$. The suspension was centrifuged at $10000 \mathrm{rpm}$ for 10 min and filtered (Whatman No. 42). The cell free filtrate was used as PPC extract to assay lipase activity.

Method: Lipase activity was assayed by a standard titrimetric method (Papaparaskevas et al., 1992) using Tri-butyrin (Glycerol tributyrate) as a lipase enzyme substrate.

One $\mathrm{ml}$ of PPC extract in a $100 \mathrm{ml}$ Erlenmeyer flask was mixed with a $10 \mathrm{ml}$ of phosphate buffer $(0.2 \mathrm{M} \mathrm{pH} 7.5) ; 1 \mathrm{ml}$ of tributyrin $1 \mathrm{ml}$ of $0.5 \mathrm{M} \mathrm{CaCl} 2$; and $0.1 \mathrm{ml}$ of $0.1 \mathrm{M}$ $\mathrm{MgCl} 2$. The reaction mixture was incubated at room temperature $\left(28^{\circ} \mathrm{C}\right)$ for $15 \mathrm{~min}$. Lipase activity was arrested after $15 \mathrm{~min}$ by adding 20 $\mathrm{ml}$ of absolute alcohol. About $0.5 \mathrm{ml}$ of phenolphthalein indicator was then added in the reaction mixture and titrated against $0.5 \mathrm{~N}$ $\mathrm{NaOH}$ in the burette. Appearance of pink color indicated end point. In the blank lipase activity was arrested by adding $20 \mathrm{ml}$ of absolute alcohol before incubation and followed the same protocol as for test sample.

Lipase activity was calculated from the difference between the titration reading (volume of $0.5 \mathrm{~N} \mathrm{NaOH}$ required) of the test sample and the blank using a standard formula. One unit of lipase activity was defined as the amount of enzyme that liberates one micromole of free fatty acid per min per gram of the substrate under the assay conditions and expressed as units per gram (U g-1) i.e. lipase units per gram of dry PPC extract. The results of lipase assay are shown in Table 1, Figure. 1.C.

\section{Results and Discussion:}

The mold growth and sporulation was prominent on PPC substrate after $24 \mathrm{hr}$ of incubation at $28^{\circ} \mathrm{C}$. N. intermedia MTCC 1230 and $R$. oligosporus MTCC 556; was noted to be fast growing fungus taking only about 28-30 hours to cover the PPC substrate. These observations coincided with those by Steinkraus et al. (1965).

The activity assay of the enzymes, amylase, protease and lipase shown in Table1, Figure. 1.A 1.B 1.C revealed that $N$. intermedia MTCC 877 and $R$. oligosporus MTCC 556 under similar conditions. All the mold cultures were noticed to show less enzyme activities after $24 \mathrm{hr}$ of PPC fermentation than those after $48 \mathrm{hr}$. There was decline in enzymes activity after $72 \mathrm{hr}$ of PPC fermentation. This indicated that $48 \mathrm{hr}$ at $28^{\circ} \mathrm{C}$ was optimum period of incubation for maximum activity of enzymes in PPC fermentation.

Our results were similar to those reported by Van Veen et al. (1968); Wang et al., (1965). Young and Wood (1977) reported that, overgrowth and excessive sporulation of the mold culture after $72 \mathrm{hr}$ of incubation causes very active deamination of amino acids resulting in decreased enzymes activity.

Comparison of enzymes assay after 48 hr. of PPC fermentation at $28^{\circ} \mathrm{C}$ shown in Table1, Figure. 1.A, 1.B, 1.C revealed that $N$. intermedia MTCC 1230 show comparatively higher activity of the enzymes amylase $(0.75 \mathrm{SU}$ $\mathrm{ml}-1)$, protease (180U $\mathrm{ml}-1)$ and lipase (4.60 U g-1) whereas R. oligosporus MTCC 556 show comparatively less activity of the enzyme, amylase (0.57 SU ml-1), protease (100 U ml-1) and lipase (2.60 U g-1) activity (Kumbhare et.al, 2003, 2014). 
Table1 : Comparison of enzymes assay after 48 hours of PPC Fermentation

\begin{tabular}{|c|c|c|c|c|}
\hline \multirow{2}{*}{$\begin{array}{l}\text { Sr. } \\
\text { No }\end{array}$} & \multirow{2}{*}{$\begin{array}{l}\text { PPC } \\
\text { Fermented } \\
\text { with Mold } \\
\text { cultures }\end{array}$} & \multicolumn{3}{|c|}{$\begin{array}{l}\text { Activity Assay of the } \\
\text { enzymes }\end{array}$} \\
\hline & & $\begin{array}{l}\text { Amylase } \\
\left(\text { SUml }^{-1}\right)\end{array}$ & $\begin{array}{l}\text { Protease } \\
\left(\mathrm{U} \mathrm{ml}^{-1}\right)\end{array}$ & $\begin{array}{c}\text { Lipase } \\
\left(\mathrm{Ug}^{-1}\right)\end{array}$ \\
\hline 1. & \begin{tabular}{|l|}
$N$. intermedia \\
MTCC 1230
\end{tabular} & 0.75 & 180 & 4.60 \\
\hline 2. & \begin{tabular}{|l|} 
R. oligosporus \\
MTCC 556
\end{tabular} & 0.57 & 100 & 2.60 \\
\hline 3. & \begin{tabular}{|l|} 
Control \\
(unfermented \\
PPC)
\end{tabular} & 0.12 & 8 & 0.33 \\
\hline
\end{tabular}

FIGURE. ENZYMES ACIVITY ASSAY IN PPC FERMENTATION

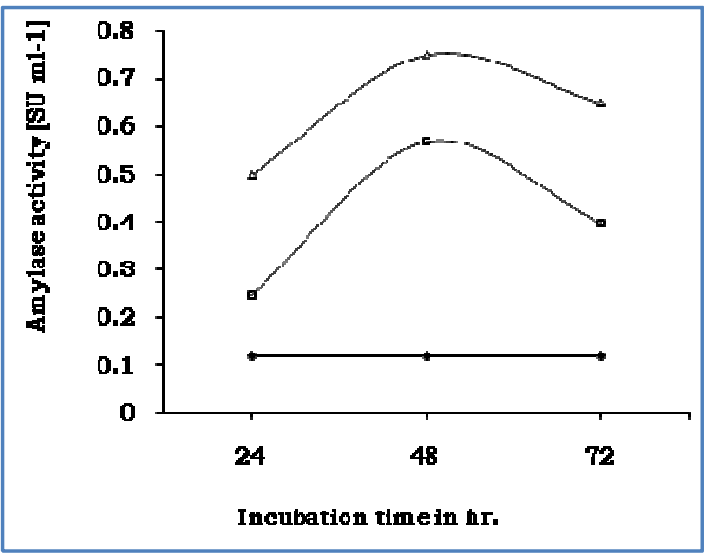

Figure. 1. A Amylase activity assay

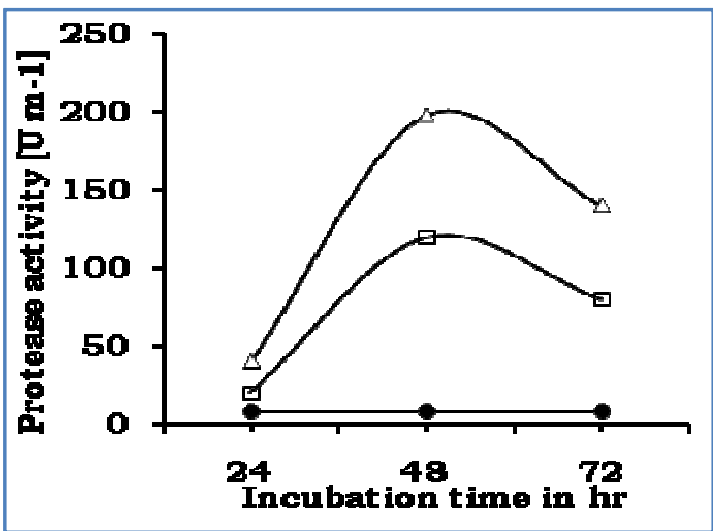

Figure. 1. B Protease activity assay

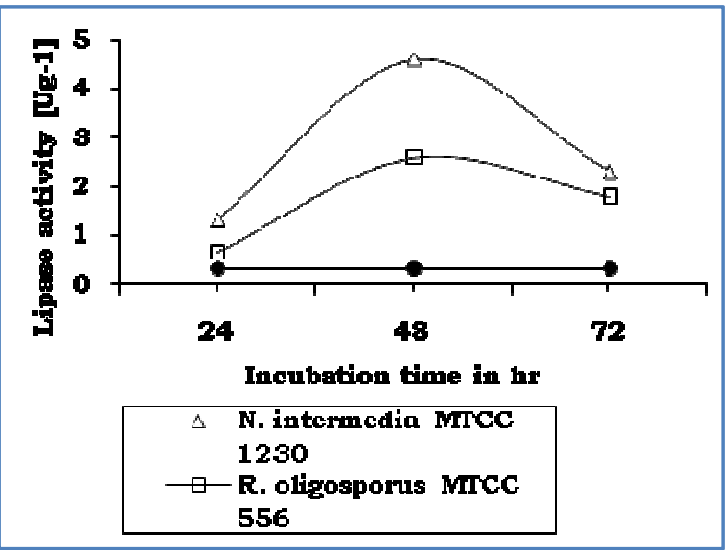

Figure. 1.C Lipase activity assay
Initial pH 6.2 of soaked PPC substrate, its $70 \%$ moisture content (relative humidity) and incubation at $28^{\circ} \mathrm{C}$ was found to be suitable for maximum activity of the enzymes amylase, protease and lipase produced by the mold cultures used in laboratory scale fermentation of PPC.

Morita et al. (1998) studied the production and assay of Gluco-amylase (Amyloglucosidase EC 3.2.1.3) and acid protease (EC 2.4.23.6) in solid-state fermentation of wheat bran. Has et al. (1992) studied extracellular lipase (EC 3.11.3) produced by $R$. delemar ATCC 34612. Ramamurthy and Kothari (1993) reported fungal protease production by solidstate fermentation.

\section{Conclusion:}

Our results concluded that, optimum activity of the enzymes amylase, protease and lipase exhibited by mold cultures during solid state fermentation of peanut press cake at $28 \mathrm{oC}$ temperature for $48 \mathrm{hr}$ may liberate simple sugars, amino acids and free fatty acids for flavor, texture, digestibility and nutritive value in fermented PPC. Hyper strains of the mold showing higher enzymes activity were selected for further biochemical studies on fermented peanut press cake.

\section{References:}

1. Arasaratnam, $\mathbf{V}$ and Mylvaganam, $\mathbf{K}$. (2001), Glucoamylase production by $A$. niger in SSF of Paddy husk as support. Jr. Food Sci. Techno. 38(4), Pp. 334-338.

2. Beuchat L. R. (1976), Fungal fermentation of peanut press cake. Jr. Economic Botany. 30, Pp. 227-234.

3. Beuchat L. R. (1983), Indigenous fermented foods. Biotechnology of food and feed production with Microbes. Verlag Chemie Weinhelm, Vol. 5. Pp. 477-528.

4. Blain J. A. (1975), Industrial enzymes production. Filamentous fungi Vol.1, Edward Arnold Pub, London. Pp. 193-211.

5. Follin, $O$ and Ciocalteu, V. (1927), Protease estimation by Follin-Ciocalteu reagent. Jr. Biol. Chem. 73, Pp. 627.

6. Kovac, B. (1997) Use of the mold Rhizopus oligosporus in food production. Food Technology and Biology, Academy Press, Washington DC, USA. Pp. 321-325

7. Kumbhare P.H. and Khandwekar P.V. (2000), Biochemical studies on "Oncom", Orient fungal food fermentation. Jr. Microbial World. Vol.3 No.1, Pp. 31-35. 
8. Kumbhare P. H. (2011). Utilization of peanut press cake for the production of Protein-rich Food Oncom and Acid protease, a commercially valuable enzyme. Jr. Microbial World. Vol.-13, No. 1, Pp. $44-49$

9. Kumbhare P. H. (2014). Analysis of Nutritive Value of Peanut Press Cake Fermented by $N$. sitophila NCIM 899 and $R$. oligosporus NCIM 1215. International Jr. of Researches in Biosciences, Agriculture and Technology (IJRBAT). Issue-2 Vol.-II, Pp. 272 - 280.

10. Lowry, O.H.; Rosenberg, N.S.; Far, A. L. and Randall, R. J. (1951), Protein measurement with Follin-Phenol reagent. Jr. Biol. Chem. 193, Pp. 265-267

11. Miall, L.M. (1983) Historical development of the fungal fermentation Industry. Filamentous Fungi, Edward Arnold, London Vol.1. Pp.104121

12. Morita H. and Matsunaga, M. (1998), Comparison of raw starch digesting Glucoamylase production by Rhizopus strain in SSF. Jr. Gen. Appl. Microbiol. 44, Pp. 211-216.
13. Papaparaskevas D. and Christakopolos, $\mathbf{P}$. (1992), Titrimetric estimation of lipase. Biotechnology Letter. 14, Pp. 397-400

14. Quinn M.R. and Beuchat L.R. (1975), Functional property changes resulting from fungal fermentation of Peanut flour. Jr. Food Science. 40, Pp.475-478.

15. Somogyi M. (1938), Methods of amylase estimation. J. Biol. Chem. 125, Pp. 399-401.

16. Van Veen A. and Graham D. (1968), Fermented Peanut press cake. Jr. Cereal Science Today. 13, Pp. 96-99.

17. Wang H.L. and Heseltine, C.W. (1965), Studies on extra cellular proteolytic enzymes of R. oligosporus. Canadian Jr. of Microbiology. 11, Pp. 727-732.

18. Young, F.M. and Wood, B.J.B. (1977), Biochemical changes in experimental Soy sauce Koji. Jr. Food. Technol. 2, Pp. 163-175. 